anthropology \& materialism

\section{Anthropology \& Materialism}

A Journal of Social Research

Special Issue | I| 2017

Discontinuous Infinities

\title{
Critique is a Philosophy of the Spirit
}

Comparing Benjamin and Fichte's Programmes for the Coming Philosophy

\section{Elise Derroitte}

\section{(2) OpenEdition \\ 1 Journals}

\section{Electronic version}

URL: https://journals.openedition.org/am/731

DOI: $10.4000 / a m .731$

ISSN: 2364-0480

\section{Publisher:}

CETCOPRA, CRASSH - Center for Research in the Arts Social Sciences and Humanities, Fakultät

Gestaltung - Universität der Künste Berlin

\section{Electronic reference}

Elise Derroitte, "Critique is a Philosophy of the Spirit", Anthropology \& Materialism [Online], Special Issue | I | 2017, Online since 02 March 2017, connection on 21 September 2021. URL: http://

journals.openedition.org/am/731 ; DOI: https://doi.org/10.4000/am.731

This text was automatically generated on 21 September 2021.

Tous droits réservés 


\title{
Critique is a Philosophy of the Spirit
}

\author{
Comparing Benjamin and Fichte's Programmes for the Coming \\ Philosophy
}

Elise Derroitte

\section{Introduction}

Even though Benjamin had chosen to dedicate his doctoral dissertation, The Concept of Criticism in German Romanticism (1919), to the relationship between Schlegel and Fichte's conceptions of reflection, ${ }^{1}$ one has to admit that his scholars have very often assimilated this Fichtean heritage to a passage-obligé between Kant and the Romantics, with too little attention being paid to the importance of this figure in Benjamin's later works. ${ }^{2}$

It is true that the references to Fichte gradually disappear in Benjamin's later writings. Nonetheless, Fichte's influence on Benjamin's philosophy of experience has been excessively downplayed in the reception of his work. ${ }^{3}$ Despite his imprecision and the idiosyncratic use that Benjamin makes of Fichte's legacy, ${ }^{4}$ his conception of critique remains deeply influenced by Fichte's conception of the process of the construction of knowledge, as developed in his Science of Knowledge (1794). In fact, Benjamin's obsession with history and experience has roots in a transcendental philosophy, the aim of which is to construct the conditions of possibility of experience within a concrete history. Therefore, this article has made the heuristic choice to compare these two essays on the purpose of philosophy, in order to show that the theoretical affinities between Fichte and Benjamin enable a deeper understanding of the role played by the operation of critique in Benjamin's later political philosophy. Why an inquiry into Benjamin's concept of critique does more than elucidate a question specific to literary criticism, by leading to the question of the political commitment of critical philosophy, is understandable from the similarities between Benjamin's opposition between 'critique' and 'commentary', outlined in "Goethe's Elective Affinities" (1924), and Fichte's opposition between philosophers of the letter and philosophers of the spirit in On the Spirit and the Letter in Philosophy, A Series of Letters, $1795 .{ }^{5}$ This comparison shows that Benjamin and Fichte's views concerning the 
affective relation that the philosopher entertains with his object of study are remarkably close. In fact, Benjamin's conception of commentary as the study of the material content of a text has important affinities with Fichte's conception of the philosopher of the letter who only considers the content [Inhalt] of a text. Conversely, both authors develop an alternative posture - that of the critic (Benjamin) and that of the philosopher of the spirit (Fichte) - which focuses on the relation to the truth content [Gehalt] of the works. This truth content implies a relation of intimacy between the subject and the object that it targets.

\section{Critique as Self-Education}

This paper aims to underline the relationship between the practice of philosophy and the intensification of common experience [Erlebnis]. As such, it concerns what we can call a process of self-education. What is at stake here is to show that the dynamic conception of both the critic and the philosopher implies a transformation of the subject. This transformation occurs when the subject appropriates the experience she has of an object. Thereby, I hope to demonstrate that the distinction, which Benjamin and Fichte make between the different ways to approach a text, is not based on its immediate content [ Inhalt]. Rather, it concerns its inner form as content [Gehalt]. Such content is extracted during the subjective and active reception of the book. Therefore, the notions of critique and of spirit are both associated with the ideas of transformation and selftransformation. ${ }^{6}$ However, how to understand critique as an auto-pedagogical activity has not yet been made obvious here. This interpretation requires three operations inherent in the activity of critique, which lead to self-learning. The first operation concerns the reason that a text is read, the second concerns the involvement of the reader, and the last one concerns the intimacy between the subject and the object, which is - as we shall see in the second part of this article - what Fichte calls the aesthetic drive.

\section{I.1. Commentator and Critic}

The first similarity between Fichte and Benjamin concerns the way a reader approaches a text. Both authors distinguish between two different forms of reception of a text, namely the reception of the letter and the spirit for Fichte, and the commentary and the critique for Benjamin. The first mode of reception for each author - namely, the philosophy of the letter and the commentary - is directed towards the immediate content [Inhalt] of the text. It pays attention to the text's material aspects. The second method of reading namely, the philosophy of the spirit and the critique - focuses on the forthcoming reception of the text. It is prospective. Therefore, these two divergent views of the activity of reading imply two different conceptions of philosophy, and philosophy-ofliterature, respectively. In “Goethe's Elective Affinities", Benjamin clearly defends his critical methodology in opposition to a philological tradition:

The writings we have on works of literature suggest that the minuteness of detail in such studies be reckoned more to the account of the interests of philology than of critique. The following exposition of Elective Affinities, which also goes into detail, could therefore easily prove misleading about the intention with which it is being presented. It could appear to be commentary; in fact, it is meant as critique. Critique seeks the truth content of a work of art; commentary, its material content. ${ }^{7}$ 
Why is Benjamin so specific about his intentions? What are those two different contents [ Gehalte] of a text? The main distinction between those two forms of reception, and by way of consequence, between these two forms of content, concern the motive, the drive that directs the reader when she experiences the text. A commentator tries to determine the correct interpretation of a text. She studies the grammatical structures in detail, as well as paying attention to the etymology of the terms employed or the grammatical use and history of the expressions; she may draw a genealogy of the concepts in the poet's oeuvre.

By contrast, the critique is based on the experience of the text by the reader herself, the reading is completed with the historical reception of the text inside the subject's affectivity. Benjamin defined this methodology in his doctoral thesis, where he explains his own heuristic choices in the following terms:

The present work is conceived as a contribution to an investigation into the history of a problem, and will endeavour to demonstrate the concept of criticism in the transformations through which it has passed. It is undeniable that such an investigation of the history of the concept of criticism is something quite different from a history of criticism itself; it addresses a philosophical or, more precisely, a problem-historical task. ${ }^{8}$

The language used in this passage, namely the idea of a problem-historical task [ problemgeschichtliche Aufgabe], relates immediately to the question of the history of the object, as well as the subject who historicizes it. The notion of a task implies a form of porosity between the subject and the object. Consequently, the difference between commentary and critique is not related to the quality of the object of analysis, but to the way the subject addresses his questions and finds answers in his readings.

This distinction between an archaeological reading of texts and a prospective one consists in the fact that critique is more focused on the task devoted to the reader (of constructing his own questions), rather than on the definite resolution of an abstract problem. As Benjamin explains when he criticizes scientific verism in the "Epistemo-Critical Prologue " to his study on the German Trauerspiel (1928):

Such a verism must then, in its treatment of the individual problem, necessarily be confronted by the genuine questions of methodology which are ignored in its scientific credo. The solution of these problems will generally lead to the reformulation of the whole mode of questioning along the following lines: how is the question, 'what was it really like?' susceptible, not just of being scientifically answered, but of actually being put. ${ }^{9}$

Critique becomes a process of historical auto-critique whereas commentary ultimately tends to a solution of a problem. When Benjamin defines his work as a task, he assumes that the result of his work will not be solely the explanation of a text but also the conception of a philosophical question. This opposition is central in Fichte's analysis of the philosophy of the spirit.

\section{The Spirit and the Letter}

Before exploring the elective affinities between Benjamin and Fichte's visions of the role of the philosopher, a brief clarification needs to be added about Fichte's On the Spirit and the Letter in Philosophy, A Series of Letters, 1795. These letters consist of a fictional dialogue between a philosopher and an amateur of philosophy. ${ }^{10}$ They are not written for experts but, rather, for any lay reader of philosophical writings. The immediate consequence of this vulgarisation of the philosophical method is that it requires a deconstruction of the 
(conceptual, institutional, social) habits of philosophical thought. Therefore, its conditions of legitimacy and comprehension cannot be found in the simple perpetuation of traditional questions and ways of asking them. The attention that Fichte pays to the reception of philosophical discourse changes the method of the creation of thought itself. As Fichte puts it: "As far as instructing your neighbour is concerned - well, the experience you will gain will be informative at least for yourself". ${ }^{11}$ This conception coincides with Benjamin's view that any critical analysis, first, leads to a process of auto-critique.

Once this framework is set, Fichte articulates the question that directs his reflection: "what is meant by the spirit of philosophy, and the spirit in philosophy", and how does it differ "from the letter as such and from the merely literal?"12

This question echoes in Benjamin's theory of critique, where it is translated as follows: what is meant by the critique of a text that concerns the truth content [Wahrheitsgehalt] and how does it differ from the commentary that concerns the material content [ Sachgehalt]? According to both authors, ${ }^{13}$ the question of spirit determines the meaning of a philosophy for the subject's spiritual life, i.e. one that targets her intellectual and material problems, not the abstract verism of scientific self-perpetuation.

\section{II.1 Philosophy of the Letter}

Fichte precisely describes the two attitudes towards texts he wants to oppose. The first one is exposed in the following passage:

You remember the complaints you made when you were reading a certain book, highly acclaimed by some. You could not read yourself into it. You had it in front of you, and your eyes were firmly fixed on it, but you found that every time you began to think about yourself you were miles away from the book. Each of your attempts to get to grips with the content and the action failed, and every time you thought you had neared grasping the unyielding spirit of the text, it slipped out of your hand. ${ }^{14}$

This citation underlines the distance between subject and object when her interrogations are not met. This distance, then, needs to be compensated by an injunction, an external obligation that forces the subject to read..$^{15}$ Here, we are witnessing a process of externalization of the motive to read that renders its experience impossible. Such impossibility is not an ontological determination of the reader; rather, it is premised on two conditions: firstly, that the subject is not attracted by the book and, secondly, that she transforms her lack of interest into a duty. It is this injunction, which comes from outside, which separates the means and the ends that makes the subject feel guilty.

You had to remind yourself continually that you wanted to study this book, indeed

that you had to (...) in order to put up with the constant feeling of resistance. (...)

Did the fault rest solely with you, with your lack of attention and your own inability

to relate to the depth and profundity of that book? ${ }^{16}$

This citation repeats the aforementioned double determination that leads to culpability: on the one hand the external imposition of a mode of relationship to the object and, on the other hand, the sense of the subject of her incapacity to realise this form of experience imposed from outside. ${ }^{17}$ This implies first a transformation of the absence of desire into a duty, and, second, an internalization of this duty into guilt. Since the subject cannot find in her feelings a motive to continue reading or acting, she searches for reasons of absolute necessity elsewhere: 'You had to remind yourself continually that you wanted to study this book, indeed that you had to (...) in order to put up with the constant 
feeling of resistance', writes Fichte..$^{18}$ And, simultaneously she experiences her lack of desire as a failure. This process of the subject's alienation and self-alienation from the authority of tradition is part of the reason that she fails at reading, understanding, committing. It is because the subject denies herself the right to choose that she is ultimately defeated..$^{19}$

\section{II.2. Philosophy of the Spirit}

This first description of a failed and constrained study allows us to deduce how Fichte explains a more affective and self-realizing way of reading. The second form in which to experience a book involves spirit and is not led by obligation and culpability:

The mood you found yourself in when reading the work of other no less profound writers allowed you to form a more favourable opinion of yourself. You felt drawn to and captivated by them. You did not need to remember your resolve to study, or the advantages you hoped to gain. When your mind was totally engrossed by what you were reading you had no need to look for any reason beyond reading it for its own sake, and the only thing that troubled you was tearing yourself from it when other duties called you away. ${ }^{20}$

In this second form of experience, the subject is not forced to read through the creation of an external constraint. Instead, it is the text that attracts and calls the reader. Fichte's philosophy of spirit considers the potential relationship to the book. It is neither an assessment of the ability of the reader, nor of the intrinsic value of the object; rather, it considers the way in which the subject is affected by the object, i.e. the way in which she accepts being transformed by it. To summarize, Fichte sketches two possible types of experience of the object:

Thus this is with books, and thus with other works of art (...). One thing leaves us cold and disinterested, or even repels us; another attracts us, invites us to linger awhile in contemplation and lose ourselves in it. ${ }^{21}$

The difference between the two attitudes is not related to the material content - both texts are good - it is related to the truth content, i.e. the questions that the text allows the reader to ask. It thus concerns the desire, the drive that the subject experiences as emanating from the object. In this sense, the differentiation between Buchstabenphilosophie [philosophy of the letter/character] and Geistesphilosophie [philosophy of the spirit] ought to be understood, above all, as a difference between practices of reading. Do I read a text to 'lose myself in it', to intensify my relation to myself and to the world, or do I read it because I want to gain knowledge?

Likewise, the difference between commentary and critique in Benjamin's text on Goethe's Elective Affinities is also based on the attitude of the reader. As we have shown, Benjamin's critique is always based on the attraction of the subject who criticises, and her availability to be transformed by this experience. In the following quotation, he distinguishes the attitudes of the commentator and of the critic.

If, to use a simile, one views the growing work as a burning funeral pyre, then the commentator stands before it like a chemist, the critic like an alchemist. Whereas, for the former, wood and ash remain the sole objects of his analysis, for the latter only the flame itself preserves an enigma: that of what is alive. Thus the critic inquiries into the truth, whose living flame continues to burn over the heavy logs of what is past and the light ashes of what has been experienced. ${ }^{22}$

Benjamin follows the path inaugurated by Fichte: the distinction he makes between commentary and critique is related to the way in which the subject is involved in the 
experience of the object. The commentator understands experience as the objective heritage of tradition that has no connection to the reader's life. The critic concerns herself with the relation between the intellectual experience of the subject and the materiality of the object that produces it. Only the latter form of experience allows for critique because it introduces something that was not present in the first form of reading: a dialogue between the reader and the text.

In the previous quote from Benjamin, we saw that the commentator remains before the pyre, in much the same way as the reader of the letter is unable to forget himself in the book. By contrast, the critic and the philosopher of the spirit try to deepen their experiences with respect to what they read; they integrate themselves in their task. As we can see, both philosophers put the question of attraction at the heart of the activity of philosophy. The purpose of studying is not to impose a definite interpretation of a work for future readers. It is to make the work grow in the future, to ensure its afterlife. ${ }^{23} \mathrm{By}$ experiencing the text and actualising its interpretation, the critic emancipates herself from the injunctions of tradition (the common interpretation of a text or the quasireligious respect for the fullness of a work of art). She commits, instead, to relate to the text from her own experience.

However, this form of interest is not the simple expression of the idiosyncrasies of the subject. Such an attitude would finally be similar to the philosophy of the letter or of the commentary in the sense that there would be a perpetuation of already existing experience [Erfahrung] that leaves no place for self-education. If this were the case, then the purpose of the experience would be lost. In fact, the issue here is not to determine a universal form of aesthetic experience but to understand how the subject constructs her own Erfahrung through her lived experiences.

Such a historical interpretation of the diachronic constitution of subjectivity avoids the fixity of the Kantian conception of experience that is unable to integrate affectivity and creation of new forms of knowledge and self-knowledge in relation to objects in general, and works of art in particular. Benjamin considers this conception in Kant to be a form of blindness with respect to the notion of experience; Fichte calls it 'the scandal of the thing-in-itself'. In reaction to this 'scandal', Fichte develops a dynamic theory of aesthetic experience.

This much is clear: that a work [which draws us to it so powerfully] may excite, stimulate, and strengthen our appreciation of and capacity to appreciate its subject matter; that such a work is not simply the object of our intellectual engagement, for it gives us at the same time the ability to engage ourselves with it, so that we receive not just the gift but the hand with which we must grasp it. Such a work creates the spectacle and the audience at one and the same time..$^{24}$

This quotation unveils Fichte's concerns for the historical reception of a work of art. If the work were totally finished, it would not be able to support the subject's interpretations and reflections. The notion of experience that Fichte constructs is, in this sense, similar to the notion of critique that Benjamin will develop throughout his early writings, and which will remain prevalent in his later productions.

The desire that Fichte mentions (and that Benjamin also considers) does not only produce the object but also the ability to apprehend it. The work of art appears as an object and as a space of experimentation, where the spectacle and the audience are created simultaneously [zugleich]. Fichte describes the new experimentation that emerges from the involvement of the subject when he says that the subject loses herself in her reading. 
In this new experience, he develops a novel understanding of himself and of the object. Benjamin also emphasizes the fact that it is precisely the interest of the subject for the object she experiences, which qualifies the nature of the experience, and not the qualities of either the individual subject or the individual object.

We find a similar definition in the "Epistemo-Critical Prologue" to The Origin of German Tragic Drama, where - invoking Plato's Symposium - Benjamin writes:

[The Symposium] declares truth to be beautiful. (...) If truth is described as beautiful, this must be understood in the context of the Symposium with the stages of erotic desires. Eros (...) does not betray his basic impulse [Bestreben] by directing his longings towards the truth; for truth is beautiful: not so much in itself, as for Eros. And so it is with human love; a person is beautiful in the eyes of his lover, but not in himself (...). Likewise truth; it is not so much beautiful in itself, as for whomsoever seeks it. ${ }^{25}$

This echoes the author's analysis of Hölderlin's poetry. As he argues:

[Life] is not the precondition but the object of a movement accomplished with a mighty freedom: the poet enters into life; he does not wander forth in it. ${ }^{26}$

In this passage Benjamin tries to articulate the relation between the subjective experience of life and freedom. The poet is not submitted to the life that precedes him; he constructs, from the moment of his experience, his life with the object. Critique, in this text, as well as in Fichte's conception of spirit, is an act of subjective construction.

Furthermore, Fichte's theory of the drives aims to locate this original subjective activity [ Thathandlung] in self-education. ${ }^{27}$ The creative relationship to the object, previously described by the notion of the erotic relation to truth, is what Fichte calls the aesthetic drive $[$ Ästhetische Trieb]:28

The one thing in man which is independent and utterly incapable of being determined from outside, we call "drive" [Trieb]. This and this alone is the single and highest principle governing self-activity [Selbsthätigkeit] in us. This alone makes us independent, observing and acting beings. (...) We need self-activity in order unceasingly to intensify and extend our cognitive knowledge of objects. ${ }^{29}$

This notion of drive, according to Jean-Christophe Goddard, determines the way in which the activity of the I appears when taken objectively: it has no reality in itself. ${ }^{30}$ This allows Fichte to bypass the question of the 'assessment' of experience from the outside. As Fichte puts it in his second letter:

[The aesthetic drive] is not directed at anything outside man, but toward something which is only to be found within him..$^{31}$

Fichte distinguishes three different drives ${ }^{32}$ - theoretical, practical and aesthetic - that initiate the different activities of the subject (knowing, acting, and feeling). The purpose of the aesthetic drive is pure representation [Vorstellung] with no relation to an object. When it becomes knowledge, it is called the knowledge-drive, and when it produces an action, it is called the practical drive. Fichte qualifies the task of the aesthetic drive as creating "the image in the soul" ${ }^{33}$ As Fichte puts it: "As far as [the aesthetic] drive is concerned, the representation is an end in itself. It does not derive its value from harmonizing with the object (...) but has value in itself. It is not the replication of reality but a free unrestrained form of the image which is sought". ${ }^{34}$ These activities are the result of the self-activity of the subject. Such an absolute activity of the self can be tracked down through the traces it leaves. For example, the practical drive is only visible through the tendency that the drive took. This tendency can take the form of a desire, in case the solution does not depend on the subject's power. It can be volition when the 
subject has the power to realise his practical drive. The aesthetic drive itself can only be exteriorized through a feeling of pleasure and displeasure. Here, the idea that it is the free drives of the subjects that determine the quality of the experience is quite revolutionary, especially as far as learning is concerned. According to both authors, the question of subjective freedom has priority over every other question. The controversy between Fichte and Schiller, concerning the place of volition in the commitment of the subject in aesthetic education, is in the background of the former's text. It remains crucial because it paves the way for their subsequent debates about the role of practical philosophy. ${ }^{35}$ Is reification the responsibility of the subject? Is it a sign of her lack of volition? Or, on the contrary, is it the result of a struggle inside the subject between her drive and the resistance of the object?

\section{Conclusion}

The question of the opposition between commentary and critique is not a technical question proper to philology. On the contrary, it addresses the political question of the role of philosophy in enhancing subjective abilities to learn and to emancipate herself from a system of oppression. The interest in developing Fichte's contribution to this Benjaminian question lies in the fact that it clarifies how to articulate the practice of philosophy through the notions of auto-critique and self-determination. This articulation is present as a framework in Benjamin's notion of critique even though it is not explicitly developed. What can be gained from this comparison is that the notion of critique in Benjamin's early works can be extended thanks to Fichte's research into the drives. Fichte provides a strong background through which he enables Benjamin to overcome two obstacles: on the one hand, the absence - in Kant - of a systematic philosophy of history; and, on the other hand, the Hegelian conception of history as perpetual improvement. Fichte allows Benjamin to understand history as the result of the process of critique that constructs it.

These theories of critique and of the philosophy of spirit are two reflections on the practice of philosophy for the reader herself. They do not target the explanation of content; rather, they interrogate the role of the philosopher as the producer of her own method. The legacy of these reflections is to consider all knowledge as part of a process of self-knowledge. According to both authors, knowledge and self-knowledge are part of the same movement of education. While focusing on the production of knowledge rather than on its absolute legitimacy, Benjamin transforms the transcendental question of freedom into the practical question of production. Benjamin's reflections on critique, its affinities with Fichte's early aesthetic, are the canvas of his later political philosophy. Consequently, the particularity of such a critical theory resides in its collective and historical aspect. The intensification of the life of spirit (a work's truth content) participates in a broader movement towards the education of society. According to both authors, the work of art awakens desire and skills on the part of the reader. Therefore, this programme for the coming philosophy requires an understanding of thinking as a process of recursive potentialization where the objects and the subjects reinvent themselves repeatedly. 


\section{BIBLIOGRAPHY}

BENJAMIN, Walter, Selected Writings 1, 1913-1926, eds. Marcus Bullock \& Michael W. Jennings (Cambridge, MA: Belknap Press of Harvard University Press, 1996).

BREAZEALE, Daniel, Thinking Through the Wissenschaftslehre: Themes from Fichte's Early Philosophy (Oxford: Oxford University Press, 2013).

CESA, Claudio, J. G. Fichte e l'idealismo transcendantale (Bologna: Il Mulino, 1992).

CESA, Claudio, Introduzione a Fichte (Bari-Rome: Editori Laterza, 1994).

D’ALFONZO, Matteo Vincenzo, “Der Trieb des Seins in der Wissenschaftslehre 1804", in: L'Être et le phénomène, Sein und Erscheinung, eds. J.C. Goddard \& A. Schnell (Paris: Vrin, 2009), pp. 185-192.

FICHTE, Johann Gottlieb, "On the Spirit and the Letter in Philosophy in a series of Letters, 1795", in: German Aesthetic and Literary Criticism: Kant, Fichte, Schelling, Schopenhauer, Hegel, ed. David Simpson, trans. E. Rubenstein (Cambridge: Cambridge University Press, 1984), pp. 75-93.

GASCHÉ, Rodolphe, “The Sober Absolute, Walter Benjamin and the Early Romantics”, in: Walter Benjamin and Romanticism, eds. Andrew Benjamin \& Beatrice Hannsen (New York/London: Continuum, 2002), pp. 51-68.

GODDARD, Jean-Christophe, "Pulsion et réflexion chez Fichte: Une éthique pulsionnelle”, in: La pulsion, ed. Jean-Christophe Goddard (Paris: Vrin, 2006), pp. 37-55.

GÖRNER, Rüdiger, "Poetik des Wissens: Zur Bedeutung der Kontroverse zwischen Schiller und Fichte über Geist und Buchstab sowie die Grenzen beim Gebrauch schöner Formen", in: Zeitschrift für Religions- und Geistesgeschichte, Vol. 51, No. 4 (1999), pp. 342-360.

HARDER, Yves-Jean, “De la lettre à l'esprit”, in: Fichte, le moi et la liberté, ed. J.C. Goddard (Paris: Presses universitaires de France, 2000), pp. 18-36.

IVALDO, Marco, Libertà e ragione: L'Etica di Fichte (Milan: Mursia, 1992), pp. 96-98.

KOHLENBACH, Margerete, Walter Benjamin: Self-Reference and Religiosity (New York: Palgrave Macmillan, 2002).

LA VOPA, Anthony, Fichte, The Self and the Calling of Philosophy, 1762-1799 (Cambridge: Cambridge University Press, 2001).

LACAN, Jacques, The Seminar of Jacques Lacan VII: The Ethics of Psychoanalysis 1959-1960, ed. J.A. Miller, trans. D. Porter (London/ New York: Routledge, 1992).

MENNINGHAUS, Winfried, "Walter Benjamin's Exposition of the Romantic Theory of Reflection”, in: Walter Benjamin and Romanticism, eds. Andrew Benjamin \& Beatrice Hannsen (New York/ London: Continuum), pp. 19-50.

PAREYSON, Luigi, L'Estetica di Fichte (Milan: Angelo Guerini, 1997).

RADRIZZANI, Ives, “Genèse de l'esthétique romantique. De la pensée transcendantale de Fichte à la poésie transcendantale de Schlegel”, in: Revue de Métaphysique et de Morale, Vol. 101, No. 4 (1996), pp. 471-498. 
ROCHLITZ, Rainer, Le désenchantement de l'art, La philosophie de Walter Benjamin (Paris: Gallimard, 1992).

STIENING, Gideon, "Entre Fichte et Schiller: La notion de Trieb dans le Hyperion de Hölderlin”, in: Revue Germanique internationale, Vol. 18 (2002), pp. 87-103.

\section{ENDNOTES}

1. Cf. Walter Benjamin, "The Concept of Criticism in German Romanticism", in: Selected Writings 1, 1913-1926, eds. Marcus Bullock \& Michael W. Jennings (Cambridge, MA: Belknap Press of Harvard University Press, 1996), especially pp. 116-148.

2. On the question of Benjamin's reception of Fichte see, among others: Margerete Kohlenbach, Walter Benjamin: Self-Reference and Religiosity (New York: Palgrave Macmillan, 2002), especially pp. 110-117; Rainer Rochlitz, Le désenchantement de l'art, La philosophie de Walter Benjamin (Paris: Gallimard, 1992), epecially p. 67. Given the specific focus of our analysis of Benjamin's concept of critique, we will not extensively discuss why Benjamin abandons the study of Fichte's early writings. Put succinctly, Benjamin reads Fichte for his doctoral dissertation with a very precise objective in mind: to overcome the lack of theory of historical transformability in Kant's Critique, a theme he had considered as a subject for his dissertation. Benjamin's understanding of Fichte is profoundly influenced by the influence the latter had exerted on the Circle of Jena, especially Schlegel. Therefore, from a strictly philological point of view, Benjamin's own commentary on the Science of Knowledge in his The Concept of Criticism in German Romanticism is neither the most interesting, nor the most accurate. On this point see: Winfried Menninghaus, "Walter Benjamin's Exposition of the Romantic Theory of Reflection", in: Walter Benjamin and Romanticism, eds. Andrew Benjamin \& Beatrice Hannsen (New York/London: Continuum), pp. 19-50. Nevertheless, from a critical perspective, Fichte's influence remains striking if one compares Benjamin's view on critique, and Fichte's view on the spirit of philosophy. Both transform what appears initially as a merely methodological question into a pedagogical-political investigation.

3. Cf. Menninghaus, "Walter Benjamin's Exposition of the Romantic Theory of Reflection", especially pp. 19-28.

4. Cf. Rodolphe Gasché, "The Sober Absolute, Walter Benjamin and the Early Romantics", in: Walter Benjamin and Romanticism, eds. Andrew Benjamin \& Beatrice Hannsen (New York/ London: Continuum), p. 51.

5. On the question of an aesthetic philosophy in Fichte and its importance in his early writings, see among others: Luigi Paryeson, L'Estetica di Fichte (Milan: Angelo Guerini, 1997); Ives Radrizzani, "Genèse de l'esthétique romantique. De la pensée transcendantale de Fichte à la poésie transcendantale de Schlegel”, in: Revue de Métaphysique et de Morale, Vol. 101, No. 4 (1996), pp. 471-498; Rüdiger Görner, "Poetik des Wissens: Zur Bedeutung der Kontroverse zwischen Schiller und Fichte über Geist und Buchstab sowie die Grenzen beim Gebrauch schöner Formen", in: Zeitschrift für Religions- und Geistesgeschichte, Vol. 51, No. 4 (1999), pp. 342-360; Yves-Jean Harder, "De la lettre à l'esprit", in: Fichte, le moi et la liberté, ed. J.C. Goddard (Paris: Presses universitaires de France, 2000), pp. 18-36.

6. In this respect, the notion of critique is also similar to Schlegel's notion of irony, which Benjamin will analyse in his doctoral disseration. (Cf. Benjamin, "The Concept of Criticism in German Romanticism”, p. 163)

7. Walter Benjamin, “Goethe's Elective Affinities”, in: Selected Writings 1, 1913-1926, eds. Marcus Bullock \& Michael W. Jennings (Cambridge, MA: Belknap Press of Harvard University Press, 1996), p. 297.

8. Benjamin, “The Concept of Criticism in German Romanticism”, p. 116. 
9. Walter Benjamin, The Origin of German Tragic Drama, trans. John Osborne (London: Verso, 1998) p. 41-42.

10. Johann Gottlieb Fichte, "On the Spirit and the Letter in Philosophy in a series of Letters, 1795", in: German Aesthetic and Literary Criticism: Kant, Fichte, Schelling, Schopenhauer, Hegel, ed. David Simpson, trans. E. Rubenstein (Cambridge: Cambridge University Press, 1984), p. 75.

11. Ibid.

12. Ibid.

13. Cf. Fichte, "On the Spirit and the Letter in Philosophy", p. 75; Walter Benjamin, "Two Poems by Friedrich Hölderlin", in: Selected Writings 1, 1913-1926, eds. Marcus Bullock \& Michael W. Jennings (Cambridge, MA: Belknap Press of Harvard University Press, 1996), p. 19.

14. Fichte, "On the Spirit and the Letter in Philosophy", p. 76. [Emphasis added]

15. This pre-empts the Freudian notion of the super-ego. It is the process of internalization of authority that leads to culpability and self-monitoring.

16. Ibid.

17. By comparison, Benjamin translates this feeling of resistance towards acting into the notion of melancholia. The melancholic creature in The Origin of German Tragic Drama is totally paralyzed so that she lets herself depend on fate. According to the author, this is precisely what characterizes the Trauerspiel: its relation to fatality which implies that "Human actions [are] deprived of all value" because they are already determined from outside by the notion of fate which is "the entelechy of events within the field of guilt". (Benjamin, The Origin of German Tragic Drama, p. 138/p.129) Benjamin thus points to a combined process of subordination of the subject to the logic of the object, when he says: "Every feeling is bound to an a priori object, and the presentation of this object is its phenomenology. (...) If the laws which govern the Trauerspiel are to be found (...) at the heart of the mourning, the representation of these laws does (...) concern itself (...) with a feeling which is released from any empirical subject and is intimately bound to the fullness of an object" (Benjamin, The Origin of German Tragic Drama, p.139) [Translation altered]. This first process is completed by the devaluation of the subject by herself through the feeling of guilt.

18. In this regard, I take it that Anthony La Vopa is mistaken when he argues that there might be an opposition between attraction and self-determination in this text. Attraction, in this sense, is not the submission to the law of the object, but rather the subjective experience of a creative relation to it. (Cf. Anthony La Vopa, Fichte, The Self and the Calling of Philosophy, 1762-1799 [Cambridge: Cambridge University Press, 2001] p. 292)

19. This conception of the transformation of a lack of interest into a failure can be translated into Lacan's vocabulary of desire. In the seventh book of his seminar we read: "the only thing one can be guilty of is giving ground relative to one's desire." (Jacques Lacan, The Seminar of Jacques Lacan VII: The Ethics of Psychoanalysis 1959-1960, ed. J.A. Miller, trans. D. Porter [London/ New York: Routledge, 1992], p. 319)

20. Fichte, "On the Spirit and the Letter in Philosophy", p.75

21. Ibid, p.76.

22. Benjamin, "Goethe's Elective Affinities", p.298. [Emphasis added]

23. Walter Benjamin, "The Task of the Translator", in: Selected Writings 1, 1913-1926, eds. Marcus Bullock \& Michael W. Jennings (Cambridge, MA: Belknap Press of Harvard University Press, 1996), p. 254.

24. Fichte, "On the Spirit and the Letter in Philosophy", p. 77. [Emphasis added]

25. Benjamin, The Origin of German Targic Drama, p. 30-31.

26. Benjamin, “Two Poems by Friedrich Hölderlin”, p. 28.

27. For a discussion of Fichte's anthropological schema, see: Daniel Breazeale, Thinking Through the Wissenschaftslehre: Themes from Fichte's Early Philosophy (Oxford: Oxford University Press, 2013), especially pp. 75-79. 
28. Cf. Fichte, "On the Spirit and the Letter in Philosophy", p. 82.

29. Ibid, p. 79-80.

30. Cf. Jean-Christophe Goddard, "Pulsion et réflexion chez Fichte: Une éthique pulsionnelle", in: La pulsion, ed. Jean-Christophe Goddard (Paris: Vrin, 2006), pp. 37-55.

31. Fichte, "On the Spirit and the Letter in Philosophy", p.82.

32. On the Trieblehre, see: Claudio Cesa, J. G. Fichte e l'idealismo transcendantale (Bologna: Il Mulino, 1992), especially p. 103, 115, and 119; Claudio Cesa, Introduzione a Fichte (Bari-Rome: Editori Laterza, 1994), p. 152; Marco Ivaldo, Libertà e ragione: L'Etica di Fichte (Milan: Mursia, 1992), pp. 96-98; Matteo Vincenzo D’Alfonzo, “Der Trieb des Seins in der Wissenschaftslehre 1804”, in: L'Être et le phénomène, Sein und Erscheinung, eds. J.C. Goddard \& A. Schnell (Paris: Vrin, 2009), pp. 185-192.

33. Fichte, "On the Spirit and the Letter in Philosophy", p. 81.

34. Ibid.

35. To sketch the opposition between Fichte and Schiller briefly, we must recall that both authors disagreed about the sensible aspect of their philosophies. That is, Schiller - for his part accused Fichte of producing a purely rational philosophy. In response to this charge, Fichte develops his Trieb-theory in which he explains the role of sensibility in the construction of knowledge. However, Fichte and Schiller's understandings of the role of an 'aesthetic drive' are ultimately different because, according to Fichte, such a drive is a condition of possibility, whilst for Schiller it is the practical activity of creation; it has a plastic effectivity. On this point, see: Luigi Pareyson, L'Estetica di Fichte (Milan: Angelo Guerini, 1997), p. 94-95. On the difference between Schiller and Fichte, see: La Vopa, Fichte, The Self and the Calling of Philosophy, p. 283; Gideon Stiening, "Entre Fichte et Schiller: La notion de Trieb dans le Hyperion de Hölderlin", in: Revue Germanique internationale, vol. 18 (2002), pp. 87-103.

\section{ABSTRACTS}

This article is primarily concerned with the question of critique in Benjamin's philosophy with reference to his theory of experience. I seek to show that Benjamin's theories of literary criticism and aesthetic critique exceed the boundaries of commentary and contain the seeds of a political programme. I argue that Benjamin's conception of critique is deeply influenced by Fichte's conception of self-activity (Tathandlung) developed in his On the Spirit and the Letter in Philosophy, A Series of Letters, 1795. In fact, Benjamin's obsession with history and experience has roots in German Idealist philosophy, the aim of which is to construct the conditions of possibility of experience within a concrete history. Benjamin inherits this view of the political function of philosophy, which he appropriates and modifies in his writings on the notion of critique. I aim to demonstrate that Benjamin and Fichte's views concerning the affective relation that the philosopher entertains with her object of study are remarkably close. Both are convinced that political emancipation has to be rooted in the critical skills of the readers, rather than being suggested by external discourses, even the most persuasive ones.

\section{INDEX}

Keywords: Fichte Johann Gottlieb, Benjamin Walter, critique, drive, experience 